Sains Malaysiana 47(8)(2018): 1757-1773

http://dx.doi.org/10.17576/jsm-2018-4708-15

\title{
Penilaian Sifat Fisio-kimia dan Analisis Hedonik bagi Titisan Piramid Padi Tahan Kemarau Terpilih
}

(Physio-chemical Properties Evaluation and Hedonic Analysis of Selected Drought Tolerant Pyramided Rice Lines)

\author{
NoraZIYAH ABD AZIZ SHAMSUdiN*, TUAN Nur AQLILI Riana TUAN Ali, \\ MOHD IKMAL ASMUNI, NABIHAH RAIHANAH TAJUL ANUAR, \\ PUTERI DINIE ELLINA ZULKAFLI \& AMIRA ISMAIL
}

\begin{abstract}
ABSTRAK
Pembiakbakaan padi tahan kemarau menjadi agenda utama ahli pembiak baka namun ia amatlah penting bagi memastikan kultivar padi baru tahan kemarau yang bakal dihasilkan mampu memenuhi cita rasa pengguna daripada segi ciri fisio-kimia serta kualiti beras dan nasi. Dalam kajian ini, sebanyak sepuluh genotip padi yang terdiri daripada lapan titisan piramid padi tahan kemarau (PLS) dan dua induk, MR219 dan MRQ74 dinilai bagi ciri fisio-kimia dan kualitinya. Kesemua genotip mempunyai kandungan amilosa (AC) yang sederhana iaitu dalam julat $20 \%$ hingga $25 \%$ kecuali PLMR219-G1 (AC rendah - 16\%) dan induk MRQ74 (AC tinggi - 27\%). Selain itu, kesemua genotip juga mempunyai suhu pengelatinan (GT) yang sederhana, konsistensi gel (GC) yang lembut serta mempunyai bentuk beras yang tirus. Tiada perbezaan yang signifikan diperoleh antara PLs dan induk untuk kesemua atribut dalam analisis hedonik kecuali bagi ciri aroma dalam populasi MRQ74. Skor PL-MRQ74-G1 bagi ciri aroma dalam ujian sensori berbeza secara signifikan dengan induk menunjukkan bahawa nasi yang dihasilkan PL ini tidak wangi. Analisis genotip turut mengesahkan gen yang mengawal ciri aroma, alel badh2 tiada dalam PL-MRQ74-G1 disebabkan rekombinasi semasa silangan. Namun demikian, alel badh2 hadir dalam PL-MRQ74-G2 yang menyokong hasil ujian hedonik dan PL ini tidak berbeza dengan $M R Q 74$ bagi atribut aroma. Secara amnya, PLs serupa dengan beras komersial yang merupakan induk mereka bagi ciri fisio-kimia dan kualiti. PLs yang tahan kemarau ini boleh dikomersialkan kerana memenuhi cita rasa pengguna Malaysia yang sukakan nasi yang lembut dan tirus selain tempoh memasak yang singkat.
\end{abstract}

Kata kunci: Alel badh2; fisio-kimia; kualiti beras; titisan piramid padi; ujian sensori

ABSTRACT

Breeding of drought tolerant rice has become the main agenda of breeders nevertheless it is crucial in ensuring the capability of this new drought tolerant rice to satisfy customers in terms of physio-chemical properties as well as the grains and cooked rice quality. In this study, ten rice genotypes were evaluated for physiochemical properties and its quality by which eight were drought tolerant pyramided lines (PLS) and the parents, MR 219 and MRQ74. All genotypes of had intermediate amylose content (AC) ranging from 20\% to 25\% except PL-MR219-G1 (low AC - 16\%) and MRQ74 (high $A C-27 \%)$. All genotypes also had moderate gelatinization temperature (GT), soft gel consistency (GC) and slender grain shape. No significant different results were obtained between PLs and its parent for all attributes in hedonic analysis except for aromatic trait in MRQ74 population. The score of PL-MRQ74-G1 for aromatic trait in sensory analysis was significant different to $M R Q 74$ indicate that this PL is non-aromatic rice. The genotyping analysis confirmed that the gene which control aromatic trait, badh2 was absent in PL-MRQ74-G1 due to recombination during crossing. However, badh2 allele was present in PL-MRQ74-G2 which supported the hedonic analysis where this PL was not significant different to $M R Q 74$ for aromatic trait. In general, PLs were similar to commercial rice (their parent) for physio-chemical properties and quality traits. The new drought tolerant PLs can be commercialized as it satisfies Malaysian customers that favor soft and slender cooked rice besides its short cooking duration.

Keywords: Badh2 allele; physio-chemical; pyramided rice lines; rice quality; sensory analysis

\section{PENGenalan}

Padi (Oryza sativa L.) merupakan tanaman terpenting di Malaysia dengan keluasan bertanam mencecah 678,954 hektar (Jabatan Pertanian Malaysia 2015). Namun begitu, Malaysia hanya mampu membekalkan $70 \%$ keperluan padi negara manakala lebihan $30 \%$ lagi khususnya beras berkualiti tinggi terpaksa diimport dari negara pengeluar lain seperti Thailand, Vietnam dan Pakistan. Selari dengan sasaran kerajaan untuk mencapai $100 \%$ sara diri beras menjelang 2020 seperti yang termaktub di dalam Rancangan Malaysia ke-11, pelbagai kajian telah dijalankan oleh institut penyelidikan seperti MARDI, UKM dan UPM untuk menghasilkan beras berkualiti dan berhasil tinggi bagi menyumbang kepada peningkatan pengeluaran 
beras negara. Pergantungan terhadap beras import boleh mendedahkan negara dengan ketidakstabilan harga dalam pasaran makanan global seperti krisis makanan yang berlaku pada tahun 2008 .

Perubahan gaya hidup dan faktor ekonomi seperti peningkatan pendapatan, perubahan cita rasa dan pilihan gaya hidup sihat telah menyebabkan pengguna kini lebih gemar untuk memilih beras yang berkualiti tinggi dan kurang kanji. Penghasilan kultivar padi yang berkualiti tinggi pada ciri fizikal dan fisio-kimia, berhasil tinggi, serta rintang terhadap tekanan biotik dan abiotik seperti kemarau dan penyakit adalah kritikal demi menjamin kestabilan industri padi dan keselamatan sumber makanan negara.

Kandungan amilosa dilihat sebagai ciri utama yang mengawal ciri fisio-kimia kanji beras kerana pengaruhnya terhadap pengelatinan, retrodegradasi, pasting, sineresis dan juga ciri berfungi yang lain (Pang et al. 2016). Ciri AC, GT dan GC merupakan tiga ciri utama fisio-kimia kanji yang bertanggungjawab menentukan kualiti pemakanan dan memasak beras (Pang et al. 2016). Selain itu, kualiti bijian dan nasi juga penting dalam menentukan harga beras serta pilihan pengguna (Suismono 2012). Menurut Badi (2013), permintaan terhadap bijian yang berkualiti tinggi semakin meningkat di negara yang sudah mencapai sara diri yang cukup. Bagi kualiti pasaran bijian, kebiasaannya ditentukan dengan melihat ciri fizikal di samping nama kultivar, manakala kualiti masakan serta makan ditentukan oleh ciri fisio-kimia (Tokpah 2010).

Mutters (1998) menyatakan bahawa bentuk dan saiz bijian amat dititikberatkan oleh ahli biak baka dalam menghasilkan kultivar baru kerana kedua-dua kriteria ini berperanan dalam penentuan kualiti bijian. Mengikut Slaton et al. (2000), beras dikategorikan mengikut saiz bijian iaitu panjang, sederhana dan pendek. Bijian yang tidak memenuhi piawaian bagi ciri saiz, bentuk, berat dan keseragaman akan menjejaskan penerimaan pengguna terhadap sesuatu padi baru (Anon 2007). Selain faktor fizikal, kualiti beras juga ditentukan oleh persekitaran dan pengurusan tanaman khususnya pengendalian hasil semasa penuaian, pemprosesan dan pengilangannya (Badi 2013). Oleh itu, bagi menjamin penerimaan pengguna terhadap sesuatu padi baru, adalah penting bagi ahli biak baka untuk melakukan pemilihan berdasarkan bentuk dan saiz bijian sebelum dan selepas dimasak.

Ujian hedonik merupakan suatu komponen ujian afektif yang dijalankan bagi menentukan tahap kesukaan dan penerimaan pengguna terhadap sesuatu makanan (Aminah 2004). Analisis sensori pula merupakan disiplin saintifik yang digunakan untuk mengukur dan menganalisis serta mentafsir tindak balas ke atas ciri produk yang diterima oleh deria penglihatan, bau, sentuhan, rasa dan pendengaran (Stone \& Sidel 1992). Menurut Gengler (2009), industri makanan merupakan industri utama yang menggunakan penilaian ini sebagai kayu pengukur kepada ciri deria rasa dan tekstur kerana ciri ini tidak dapat diukur dengan menggunakan instrumen. Analisis sensori biasanya dijalankan sebelum sesuatu produk dipasarkan bagi mengurangkan risiko ketidakterimaan pengguna selain menambah baik atribut produk agar dapat memenuhi permintaan pengguna (Setyaningsih et al. 2010). Penerimaan masyarakat dunia terhadap beras dan nasi adalah berbeza-beza berdasarkan beberapa faktor seperti status sosial, tahap kesihatan dan negara.

Kultivar padi MR219 diperkenalkan oleh MARDI pada tahun 1999 sebagai kultivar berhasil tinggi dengan kualiti setaraf beras terbaik Thailand. Ciri istimewanya adalah matang lebih cepat berbanding kultivar sedia ada (105-111 hari), bentuk tangkai yang padu serta bilangan biji setiap tangkai yang banyak (Zainudin et al. 2012). Potensi hasil MR219 juga melebihi 10.0 tan sehektar dengan pengurusan sawah yang baik serta tambahan baja. Untuk ciri fisio-kimia pula, MR219 mempunyai AC sederhana, nisbah penggunaan air rendah dan menghasilkan tekstur nasi yang lembut (Fasahat et al. 2012). Nilai GC yang rendah dan perpecahan alkali sederhana juga menunjukkan bahawa MR219 mempunyai cita rasa nasi yang kekal lembut walaupun setelah sejuk. MARDI juga memperkenalkan MRQ74 pada tahun 2005 bagi memenuhi selera pengguna yang mahukan beras berkualiti tinggi dan pengurangan import beras wangi yang bernilai RM 500 juta setahun (Asfaliza et al. 2008). Kualiti beras MRQ74 yang menyerupai beras Basmati mempunyai potensi melebihi beras putih biasa dan dijangka dapat meningkatkan pendapatan petani tempatan. MRQ74 mendapat sambutan yang tinggi daripada pengguna tempatan kerana ciri istimewanya seperti saiz beras yang panjang dan tirus, tinggi AC, rendah GC, perpecahan alkali sederhana dan menghasilkan tekstur nasi yang beraroma, peroi dan tidak melekit (Asfaliza et al. 2009, 2008).

Kajian oleh Shamsudin et al. (2016a, 2016b) berjaya menghasilkan beberapa PL dengan kelebihan hasil 0.5 tan sehektar atau lebih berbanding induk-induk penerima iaitu MR219 dan MRQ74 dalam tekanan kemarau di peringkat reproduktif dan tanpa kemarau melalui kaedah MAB langkah demi langkah. Tiga lokus ciri kuantitatif bagi hasil ( $q D T Y$ ) iaitu $q D T Y_{2.2}, q D T Y_{3.1}$ dan $q D T Y_{12.1}$ telah dipindahkan secara serentak ke dalam MR219 dan MRQ74 dan kehadiran kesemua $q D T Y$ pada PL disahkan menggunakan penanda mikrosatelit yang berkait rapat dengannya. Walaupun PL yang tahan kemarau ataupun tahan kepada ekosistem kurang air ini berjaya dihasilkan, namun adalah menjadi cabaran utama kepada ahli biak baka padi kerana perlu memastikan setiap baka baru padi yang dihasilkan mampu bersaing dengan kultivar komersial sedia ada bagi menjamin penerimaannya oleh pengguna. Setiap titisan biak baka padi baru yang dihasilkan mestilah mempunyai kualiti pemakanan yang hampir sama atau lebih baik berbanding kultivar mega sebelum boleh dikomersialkan. Jadi dalam kajian ini, PLs MR219 dan PL MRQ74 generasi $\mathrm{BC}_{1} \mathrm{~F}_{9}$ terpilih berserta induk telah digunakan untuk menilai ciri fisio-kimia, kualiti dan ujian hedonik serta ujian penyusunan. Penilaian ciri fisio-kimia, kualiti bijian dan analisis hedonik ini penting untuk memastikan PL terpilih dapat memenuhi cita rasa pengguna tempatan. Kajian ini bukan sahaja penting dalam memastikan tahap penerimaan pengguna namun dapat melihat kejayaan program memindahan secara serentak 
beberapa $q D T Y$ ke dalam kultivar moden menggunakan kaedah MAB langkah demi langkah.

\section{BAHAN DAN KAEDAH}

Sebanyak sepuluh genotip padi yang terdiri daripada lapan PL terpilih dan dua induk penerima iaitu kultivar berhasil tinggi MR219 dan kultivar berkualiti tinggi MRQ74 telah dinilai untuk ciri fisio-kimia dan kualiti beras. Penilaian dijalankan menggunakan reka bentuk rawak lengkap dengan tiga replikasi. PL yang dihasilkan mempunyai antara $83 \%$ hingga $98 \%$ dan antara $82 \%$ hingga $90 \%$ kandungan genom induk penerima bagi populasi MR219 dan MRQ74 dengan pemilihan dilakukan berdasarkan morfologi pokok dan bentuk bijian yang sama dengan induk penerima selain ketahanannya terhadap kemarau (Shamsudin et al. 2016a, 2016b). Kesemua genotip diambil daripada percubaan hasil lanjutan (AYT) pada musim utama 2016 di Stesen Padi, Tanaman Industri dan Florikultur (PTIF), Titi Serong, Perak. Bijian disimpan selama dua bulan pada suhu bilik sebelum dianalisis. Sampel bijian dinyahkulit menggunakan mesin pengulit beras sebelum dikikis bagi memutihkannya menggunakan mesin pengilap beras dan diasingkan beras sempurna bentuk dan beras hancur menggunakan mesin penggredan. Analisis fisio-kimia yang dijalankan adalah penentuan AC dalam unit peratus menggunakan kaedah berdasarkan Juliano (1971), GT dalam unit darjah selsius menggunakan kaedah IRRI (2013) dan GC menggunakan kedah Cagampang et al. (1973). Menurut Cheng et al. (2012), AC antara 12 hingga 20 dikategorikan sebagai rendah, AC 20 hingga 25 dikategorikan sebagai sederhana dan AC melebihi 25 dikategorikan sebagai tinggi. Jadual 1 menunjukkan kategori GT berdasarkan skala pengkelasan penghadaman alkali oleh IRRI (2013). Skor bagi GC pula adalah berdasarkan Juliano dan Duff (1991). Manakala bagi kualiti beras dan nasi, data yang dicerap adalah panjang beras (RL), lebar beras (RW) dan panjang nasi (NL) dalam unit mm. Ciri RL, RW dan NL digunakan untuk menghitung nisbah panjang-lebar beras (LWR) dan ER berdasarkan formula berikut:

Nisbah panjang - lebar $($ LWR $)=\frac{\text { Purata panjang beras }(\mathrm{mm})}{\text { Purata lebar beras }(\mathrm{mm})}$
Nisbah pemanjangan $(E R)=\frac{\text { Purata panjang nasi }(\mathrm{mm})}{\text { Purata panjang beras }(\mathrm{mm})}$

Bagi penilaian hedonik pula, hanya tujuh genotip diuji yang terdiri daripada tiga PL MR219 (PL-MR219-G1, PL-MR219-G2 dan PL-MR219-G4), dua PL MRQ74 (PLMR219-G1 dan PL-MR219-G2) dan dua induk (MR219 dan MRQ74). Penilaian ini diadili oleh 30 orang panel tidak terlatih dan diuji secara berasingan antara beras biasa dan beras wangi disebabkan oleh perbezaan atributnya daripada segi aroma. Penilaian hedonik nasi dan penyusunan dimulakan dengan menyediakan helaian utama dan borang penilaian (helaian sampingan).

Sampel nasi disediakan merujuk kaedah Yu et al. (2009) dengan sedikit pengubahsuian. Sebanyak $200 \mathrm{~g}$ beras dibilas dengan air sebanyak tiga kali dan ditoskan. Kemudian, beras dimasukkan ke dalam periuk elektrik yang ditambah dengan $400 \mathrm{~mL}$ air dan dimasak selama 30 min. Apabila nasi masak, nasi dibiarkan di dalam periuk elektrik dan bertutup sepanjang penilaian. Setiap sampel nasi diisikan ke dalam bekas kecil yang disusun mengikut urutan permutasi. Panel juga disediakan sebotol air kosong untuk membilas mulut, sudu kecil (berbeza bagi setiap sampel) untuk mengambil sampel dan borang penilaian. Panel perlu menilai atribut aroma, tekstur, kelembutan, warna dan penerimaan keseluruhan dengan memberikan skor yang sesuai. Bagi ujian penyusunan pula, tiga atribut diuji iaitu aroma, rasa dan warna. Bekas sampel dilabelkan dengan kod nombor rawak tiga digit dan panel diberi satu jam untuk menulis skor bagi setiap atribut mengikut darjah kesukaan.

Bagi pengesahan gen badh2 iaitu gen yang mengawal ciri aroma, enam penanda mikrosatelit berkait rapat dengan gen badh2 digunakan dalam penilaian genotip populasi MRQ74 iaitu BADEX7-5, RM223, RM5474, L06, RM42 dan SCUSSR1. DNA diekstrak menggunakan kaedah CTAB dengan sedikit pengubahsuaian berpandukan Murray dan Thomsom (1980). Proses tindak balas rantaian polimerase dilakukan merujuk kepada Panaud et al.(1996). Gel agaros 4\% digunakan untuk elektroforesis. Produk PCR dipisahkan melalui gel elektroforesis selama 90-120 min dengan kuasa voltan $60 \mathrm{~V}$ hingga $70 \mathrm{~V}$ berdasarkan saiz produk PCR. Kehadiran alel badh2 dikesan dengan kehadiran jalur pada gel apabila dilihat di bawah sinaran radioaktif Alpha

JADUAL 1. Skala pengkelasan penghadaman alkali dan penentuan suhu pengelatinan

\begin{tabular}{lccc}
\hline Ciri & Pengkelasan & $\begin{array}{c}\text { Nilai } \\
\text { perpecahan } \\
\text { alkali }\end{array}$ & $\begin{array}{c}\text { Suhu pengelatinan } \\
\text { (IRRI 2013) }\end{array}$ \\
\hline Tiada kesan tetapi berkapur & Rendah & 1 & Tinggi (75-79 $\left.{ }^{\circ} \mathrm{C}\right)$ \\
Beras membengkak & Rendah & 2 & Tinggi \\
Beras membengkak dan terbentuk kolar yang tipis disekeliling & Rendah & 3 & Sederhana $\left(70-74^{\circ} \mathrm{C}\right)$ \\
Beras membengkak dan terbentuk kolar yang lebar di sekeliling & Sederhana & 4 & Sederhana \\
Beras terpisah atau terbahagi dan terbentuk kolar yang lebar di sekeliling & Sederhana & 5 & Sederhana \\
Beras tersebar dan bercantum dengan kolar & Tinggi & 6 & Rendah $\left(55-69^{\circ} \mathrm{C}\right)$ \\
Beras tersebar sepenuhnya dan bercampur dengan larutan & Tinggi & 7 & Rendah \\
\hline
\end{tabular}


Imager. Skor bagi saiz alel diberi dengan membandingkan saiz alel genotip iaitu MRQ74 yang membawa gen badh2.

Data dianalisis menggunakan perisian Statistik 20 IBM SPSS. Analisis varians (ANOVA) dan ujian perbezaan keertian jujur Tukey (HSD) serta perbezaan keertian terkecil (LSD) dijalankan untuk melihat perbezaan antara sampel berdasarkan aras keyakinan 95\% $(p<0.05)$.

\section{KEPUTUSAN DAN PERBINCANGAN}

\section{KANDUNGAN AMILOSA (AC)}

Julat min AC untuk PL MR219 adalah antara 16\% sehingga 21\% (Jadual 2). PL-MR219-G1 mempunyai AC terendah iaitu 16\% manakala PL-MR219-G6 mempunyai AC tertinggi, iaitu $21 \%$ yang sama dengan AC induk MR219. Kesemua PL MR219 dikategorikan kepada sederhana AC kecuali PL-MR219-G1 kerana berada antara 20\% sehingga $25 \%$. Julat AC bagi PL MRQ74 pula adalah antara 24\% sehingga $25 \%$ iaitu dalam kategori sederhana juga seperti majoriti PL MR219. Namun induk MRQ74 berada dalam kategori tinggi AC dengan nilai 27\% (Jadual 2).

Kajian terdahulu mendapati bahawa kebanyakan penduduk Malaysia lebih menggemari beras berkualiti yang tidak melekit (Asfaliza et al. 2009; Fasahat et al. 2012). Namun, beras yang tinggi AC juga boleh menghasilkan nasi yang lembut bergantung kepada nilai GC beras tersebut. Asfaliza et al. (2008) mendapati bahawa, walaupun beras MRQ74 mempunyai AC kelas tinggi, nasi yang dihasilkan adalah lembut dan tidak kering kerana nilai GCnya yang sederhana. Kesemua PL MR219 dan PL MRQ74 yang dihasilkan mempunyai AC kelas sederhana kecuali PL-MR219-G1 yang menandakan beras tersebut akan menghasilkan tekstur nasi yang tidak melekit, lembut dan peroi apabila dimasak. Oleh itu, beras daripada PL dijangka menepati cita rasa rakyat Malaysia.

\section{SUHU PENGELATINAN (GT)}

Untuk PL MR219, skor penyebaran alkali adalah lebih tinggi (3-5) berbanding PL MRQ74 (3-4). Nilai penyebaran alkali untuk kesemua genotip yang diuji dapat dikelaskan kepada pengkelasan sederhana (3-5), bererti GT adalah sederhana (70-74 $\left.{ }^{\circ} \mathrm{C}\right)$. Kesemua PL MR219 tidak menunjukkan perbezaan GT yang signifikan dibandingkan pada induk MR219 kecuali PL-MR219-G1 (Jadual 2). Bagi populasi MRQ74, tiada perbezaan yang signifikan direkodkan antara MRQ74 dan PLnya untuk nilai GT. PL-MRQ74-G1 dan PL-MRQ74-G2 berkongsi nilai GT yang rendah iaitu 3, manakala induk MRQ74 mempunyai GT tertinggi 3.7 (Jadual 2).

GT yang rendah atau sederhana adalah lebih digemari oleh pengguna kerana GT berkait rapat dengan tempoh memasak beras (Asante 2017). Menurut Fitzgerald et al. (2009), tempoh memasak beras boleh dikurangkan sehingga empat minit untuk setiap pengurangan GT. Keputusan mendapati bahawa kesemua PL MR219 dan PL MRQ74 mempunyai GT sederhana. Menurut Juliano et al. (1965), beras AC kelas tinggi mempunyai GT sederhana $\left(70-75^{\circ} \mathrm{C}\right)$ dan memerlukan tempoh memasak yang cepat iaitu antara 13 sehingga $16 \mathrm{~min}$.

\section{KONSISTENSI GEL (GC)}

Julat min GC untuk kesemua genotip adalah antara 68.0 sehingga $101.0 \mathrm{~mm}$. Bagi populasi MR219, PL-MR219-G1 yang merekodkan nilai GT tertinggi mempunyai nilai GC terendah $72.7 \mathrm{~mm}$ manakala PL-MR219-G5 yang merekodkan nilai GT yang rendah iaitu 3.3 mempunyai nilai GC yang tinggi iaitu $96.0 \mathrm{~mm}$ (Jadual 2). Kesemua PL MR219 tidak menunjukkan perbezaan GC yang signifikan dibandingkan dengan induk MR219. Bagi populasi MRQ74 pula, PL-MRQ74-G1 mempunyai nilai GC terendah iaitu $68.0 \mathrm{~mm}$, manakala induk MRQ74 mempunyai GC tertinggi, $89.0 \mathrm{~mm}$ (Jadual 2). Kesemua PL MRQ74 tidak menunjukkan perbezaan yang signifikan untuk nilai GC apabila dibandingkan dengan induk MRQ74, kecuali genotip PL-MRQ74-G1. PL MR219 dan PL MRQ74 termasuk induk berada pada kelas GC lembut, menandakan beras tersebut akan menghasilkan tekstur nasi yang kekal lembut setelah dimasak atau setelah sejuk.

JADUAL 2. Data deskriptif kandungan amilosa, suhu penggelatinan dan konsistensi gel untuk setiap genotip

\begin{tabular}{|c|c|c|c|c|c|c|c|}
\hline \multirow[t]{2}{*}{ Genotip } & \multirow[t]{2}{*}{ Latar belakang } & \multicolumn{2}{|c|}{$\begin{array}{l}\text { Kandungan } \\
\text { amilosa (\%) }\end{array}$} & \multicolumn{2}{|c|}{ Suhu pengelatinan $\left({ }^{\circ} \mathrm{C}\right)$} & \multicolumn{2}{|c|}{ Konsistensi gel } \\
\hline & & Min & Kelas & Min & Kelas & Min & Kelas \\
\hline PL-MR219-G1 & MR219 & 16 & Rendah & $4.7^{\mathrm{a}}$ & Sederhana & $72.7^{b}$ & Tinggi \\
\hline PL-MR219-G2 & MR219 & 20 & Sederhana & $4.3^{\mathrm{ab}}$ & Sederhana & $94.0^{\mathrm{ab}}$ & Tinggi \\
\hline PL-MR219-G3 & MR219 & 20 & Sederhana & $4.3^{\mathrm{ab}}$ & Sederhana & $84.7^{\mathrm{ab}}$ & Tinggi \\
\hline PL-MR219-G4 & MR219 & 20 & Sederhana & $4.0^{\mathrm{ab}}$ & Sederhana & $83.7^{\mathrm{ab}}$ & Tinggi \\
\hline PL MR219-G5 & MR219 & 20 & Sederhana & $3.3^{\mathrm{b}}$ & Sederhana & $96.0^{\mathrm{a}}$ & Tinggi \\
\hline PL-MR219-G6 & MR219 & 21 & Sederhana & $4.3^{\mathrm{ab}}$ & Sederhana & $100.0^{\mathrm{a}}$ & Tinggi \\
\hline MR219 & Induk & 21 & Sederhana & $3.3^{\mathrm{b}}$ & Sederhana & $81.7^{\mathrm{ab}}$ & Tinggi \\
\hline PL-MRQ74-G1 & MRQ74 & 25 & Sederhana & $3.0^{\mathrm{a}}$ & Sederhana & $68.0^{\mathrm{b}}$ & Tinggi \\
\hline PL-MRQ74-G2 & MRQ74 & 24 & Sederhana & $3.0^{\mathrm{a}}$ & Sederhana & $76.3^{\mathrm{ab}}$ & Tinggi \\
\hline MRQ74 & Induk & 27 & Tinggi & $3.7^{\mathrm{a}}$ & Sederhana & $89.0^{\mathrm{a}}$ & Tinggi \\
\hline
\end{tabular}

* Purata yang berbeza huruf pada lajur yang sama mempunyai perbezaan yang signifikan (Ujian Fisher, $\alpha=0.05$ ) 


\section{NISBAH PANJANG-LEBAR BERAS (LWR)}

Penampilan beras merupakan kriteria penting bagi pengguna semasa membeli beras. Menurut Dela-Cruz dan Khush (2000), LWR menentukan bentuk serta saiz kategori beras, dengan LWR melebihi 3.00 menghasilkan beras berbentuk agak tirus, LWR 2.10 sehingga 3.00 pula menghasilkan bentuk beras sederhana tirus manakala LWR 2.00 dan ke bawah menghasilkan beras yang agak bulat. Menurut Shamim et al. (2017) pula, LWR dengan nilai 3.00 dan ke atas menunjukkan penampilan beras yang menarik. Bagi populasi MR219, julat RL adalah antara 6.80 sehingga $7.41 \mathrm{~mm}$ manakala julat RW pula adalah antara 1.95 sehingga $2.39 \mathrm{~mm}$. Induk MR219 mempunyai panjang dan lebar bijian yang pendek berbanding PLnya namun mempunyai LWR yang tertinggi menunjukkan bentuk berasnya lebih tirus walaupun saiznya lebih kecil berbanding PL. Namun, kesemua PLMR219 mempunyai LWR melebihi 3.00 yang juga memberi bentuk beras yang tirus.

Bagi populasi MRQ74 pula, julat RL adalah antara 6.43 sehingga $7.71 \mathrm{~mm}$ manakala julat RW pula adalah antara 1.84 sehingga $2.03 \mathrm{~mm}$. Walaupun populasi MRQ74 mempunyai nilai LWR melebihi 3.00 seperti mana populasi MR219 namun julatnya lebih tinggi menunjukkan populasi MRQ74 mempunyai bentuk beras yang sangat tirus. Populasi MRQ74 memang dijangka akan mempunyai LWR yang lebih tinggi daripada populasi MR219 memandangkan induk MRQ74 adalah padi berkualiti tinggi dengan saiz beras yang panjang kerana berlatar belakang padi kultivar Basmati. Di Malaysia, penerimaan saiz dan bentuk beras adalah berbeza daripada satu kumpulan ke satu kumpulan pengguna yang lain namun kebanyakan pengguna menggemari beras berbentuk tirus dan panjang seperti beras Basmati.

\section{NISBAH PEMANJANGAN KERNEL (ER)}

Peningkatan isi padu serta serapan air oleh bijian ketika sedang masak menyebabkan pemanjangan panjang dan lebar bijian berlaku (Thomas et al. 2013). Di samping itu, masa memasak yang terlalu lama menyebabkan bijian akan mengalami penyepaian serta mengeriting dan untuk mengelakkannya, bijian mestilah dimasak dalam tempoh masa yang minimum (Juliano et al. 1982).

Keputusan menunjukkan bagi populasi MR219, julat min NL adalah antara 9.04 sehingga $12.46 \mathrm{~mm}$ (Jadual 3). Induk MR219 menghasilkan nasi yang paling pendek berbanding PLnya setelah dimasak $(9.04 \mathrm{~mm})$. Bagi ER pula, julatnya adalah antara 1.25 sehingga 1.72 (Jadual 3). PL-MR219-G1 dengan nilai NL tertinggi dan nilai ER tertinggi (1.72) turut mengatasi ER induk MR219 menunjukkan ia menghasilkan beras yang sangat panjang setelah dimasak. Menariknya, nilai ER PL-MR219-G1 yang merupakan PL MR219 turut mengatasi nilai ER MRQ74 dengan ciri berkualiti tinggi seperti kultivar Basmati serta berasnya dikategorikan sebagai panjang dan tirus.

MR219 pada umumnya merupakan padi berhasil tinggi namun kualitinya tidaklah setanding MRQ74 yang diketahui umum mempunyai panjang nasi yang panjang setelah dimasak. Ini menunjukkan walaupun ciri nasi yang panjang bukanlah merupakan ciri MR219 namun PLnya dapat menghasilkan ciri yang bertentangan mungkin disebabkan oleh beberapa faktor seperti wujudnya interaksi epistasis antara alel induk-induk yang digunakan dalam penjanaan PL ini selain kehadiran QTL yang mengawal ciri panjang nasi. Menurut Sood dan Saddiq (1979), pemanjangan selanjar bijian merupakan satu ciri utama beras yang berkualiti. Selain MRQ74 yang merupakan kultivar berkualiti tinggi, PL-MR219-G1 juga boleh dikategorikan sebagai berkualiti tinggi kerana menghasilkan nasi yang panjang setelah dimasak mengatasi NL dan ER MRQ74.

\section{UJIAN HEDONIK}

Min skor untuk ujian hedonik bagi atribut yang diuji seperti aroma, warna, tekstur, kelembutan serta penerimaan keseluruhan terhadap PL dan induk ditunjukkan dalam Rajah 1. Aroma adalah atribut paling utama yang perlu dinilai dan dilakukan semasa nasi masih panas. Aroma merupakan ciri berkualiti bagi beras beraroma yang dapat membezakan beras beraroma yang tinggi nilainya dengan jenis beras yang lain (Golam et al. 2010). Menurut Melissa et al. (2008), atribut ini adalah yang terpenting dalam

JADUAL 3. Data deskriptif panjang beras, lebar beras, nisbah panjang-lebar beras, panjang nasi dan nisbah pemanjangan kernel bagi setiap genotip

\begin{tabular}{lcccccc}
\hline Genotip & $\begin{array}{c}\text { Panjang beras } \\
(\mathrm{mm})\end{array}$ & $\begin{array}{c}\text { Lebar beras } \\
(\mathrm{mm})\end{array}$ & $\begin{array}{c}\text { Nisbah panjang- } \\
\text { lebar beras }\end{array}$ & $\begin{array}{c}\text { Bentuk } \\
\text { bijian }\end{array}$ & $\begin{array}{c}\text { Panjang } \\
\text { nasi }(\mathrm{mm})\end{array}$ & $\begin{array}{c}\text { Nisbah pemanjangan } \\
\text { kernel }\end{array}$ \\
\hline PL-MR219-G1 & 7.23 & 2.23 & 3.24 & Tirus & 12.46 & 1.72 \\
PL-MR219-G2 & 7.26 & 2.28 & 3.18 & Tirus & 9.07 & 1.25 \\
PL-MR219-G3 & 7.41 & 2.28 & 3.25 & Tirus & 9.45 & 1.28 \\
PL-MR219-G4 & 7.25 & 2.20 & 3.30 & Tirus & 9.30 & 1.30 \\
PL MR219-G5 & 7.20 & 2.39 & 3.17 & Tirus & - & - \\
PL-MR219-G6 & 7.29 & 2.27 & 3.21 & Tirus & 9.20 & 1.26 \\
MR219 & 6.80 & 1.95 & 3.50 & Tirus & 9.04 & 1.33 \\
PL-MRQ74-G1 & 7.23 & 1.84 & 4.00 & Tirus & 9.87 & 1.40 \\
PL-MRQ74-G2 & 7.71 & 2.03 & 3.80 & Tirus & 8.25 & 1.10 \\
MRQ74 & 6.43 & 1.90 & 3.40 & Tirus & 10.41 & 1.62 \\
\hline
\end{tabular}


menentukan harga pasaran nasi di samping mencerminkan identiti tempatan. Bagi populasi MR219, keputusan menunjukkan bahawa julat min skor bagi atribut aroma adalah antara 4.03 sehingga 4.30 , namun tiada perbezaan yang signifikan ditunjukkan bagi atribut aroma antara keempat-empat sampel yang diuji (Rajah 1(a)).

Bagi populasi MRQ74 pula, julat min skor aroma antara 3.53 sehingga 4.80 dengan min skor tertinggi adalah MRQ74 (4.80) (Rajah 1(b)). Menurut Asfaliza et al. (2008), MRQ74 mempunyai aroma yang menyerupai daun pandan seperti induknya Kashturi. Keputusan menunjukkan bahawa terdapat perbezaan yang signifikan bagi atribut aroma antara MRQ74 dengan PL-MRQ74-G1 namun tidak dengan PL-MRQ74-G2. Berdasarkan pengesahanan kehadiran alel badh2 yang mengawal ciri aroma, kesemua penanda mikrosatelit yang digunakan dalam kajian ini menunjukkan tiada perbezaan skor saiz alel badh2 pada MRQ74 dengan PL-MRQ74-G2 menunjukkan bahawa PLMRQ74-G2 turut mempunyai aroma yang wangi seperti induk MRQ74 (Rajah 2). Manakala PL-MRQ74-G1 pula tidak membawa alel badh2 dengan alel tersebut mungkin hilang akibat pindah silang yang berlaku semasa proses kacukan.

Tekstur juga merupakan atribut penting dalam memastikan penerimaan makanan oleh pengguna (Lyon et al. 1999; Moskowitz \& Drake 1972). Selain faktor pemprosesan (Rousset et al. 1995), tekstur nasi turut dipengaruhi oleh faktor lain seperti AC dan GT (Juliano \& Perez 1983). Julat min skor atribut tekstur adalah 4.37 sehingga 4.87 bagi populasi MR219 dan 4.10 sehingga 4.57 bagi populasi MRQ74 (Rajah 1 dan 2). Walaupun MR219 mempunyai min skor tertinggi (4.87) namun tiada perbezaan yang signifikan direkodkan antara keempatempat sampel daripada populasi MR219.

Seperti populasi MR219, MRQ74 juga mempunyai min skor tertinggi (4.57) namun tiada perbezaan yang signifikan direkodkan sampel populasi MRQ74. Asfaliza et al. (2008) menyatakan tekstur bagi nasi MRQ74 masih kekal lembut walaupun selepas dimasak. Walaupun min skor MRQ74 lebih tinggi berbanding PL (perbezaan tidak signifikan), namun PL juga mempunyai tekstur nasi seperti induk yang tidak melekit dan berderai kerana berada di kelas AC sederhana. Tekstur adalah manifestasi deria struktur atau dalaman produk daripada segi rasa yang diukur oleh saraf taktil di atas permukaan kulit tangan, bibir serta lidah. Ciri yang tergolong dalam tekstur termasuklah kemampatan, kelekitan, kelekatan dan kelikatan (Choi 2016). Menurut Verma et al. (2015), keseluruhan bijian nasi dimakan dan atribut yang difokuskan adalah teksturnya.

Atribut kelembutan sangat berkait dengan GC selain AC. Julat min skor atribut kelembutan bagi populasi MR219 dan populasi MRQ74 masing-masing adalah antara 4.73 sehingga 5.00 dan antara 3.90 sehingga 4.23. Namun, tiada perbezaan yang signifikan antara induk dan PLs. Seperti yang dijangka, populasi MRQ74 mempunyai skor attribut kelembutan yang rendah berbanding populasi MR219. Hal ini kerana AC populasi MRQ74 adalah lebih tinggi dan mempengaruhi kelembutan nasi. Atribut ini juga menunjukkan tiada perbezaan signifikan antara kesemua PL MR219 dan PL MRQ74 berbanding induk mereka (Rajah 1(a) dan 1(b)).

Bagi populasi MR219, PL mempunyai skor GC yang lebih tinggi berbanding induk (4.73). Ini disokong oleh AC dan walaupun PL MR219 berada dalam kelas AC sederhana, namun PL MR219 mempunyai nilai AC yang lebih rendah iaitu antara 16\% sehingga $20 \%$ berbanding induk MR219 (21\%). Oleh yang demikian, nasi PL MR219 adalah lebih lembut berbanding induknya. Menurut Adu-Kwarteng et al. (2003), AC sederhana di dalam beras lebih digemari disebabkan oleh nasi menjadi kering, gebu apabila dimasak dan kekal lembut walaupun telah sejuk. Tambahan lagi, beras yang mempunyai kandungan amilosa yang tinggi akan menghasilkan nasi yang keras apabila sejuk. Bagi MRQ74 pula, panel paling menggemari nasi MRQ74 yang mencatatkan nilai min skor GC tertinggi iaitu 4.23. Asfaliza et al. (2008) melaporkan sampel nasi MRQ74 adalah lembut walaupun kandungan amilosanya sederhana tinggi. PLMRQ74-G1 pula mempunyai min skor iaitu 4.13, manakala PL-MRQ74-G2, 3.90 mencatatkan min skor yang terendah namun tiada perbezaan signifikan antara ketiga-tiga sampel nasi.
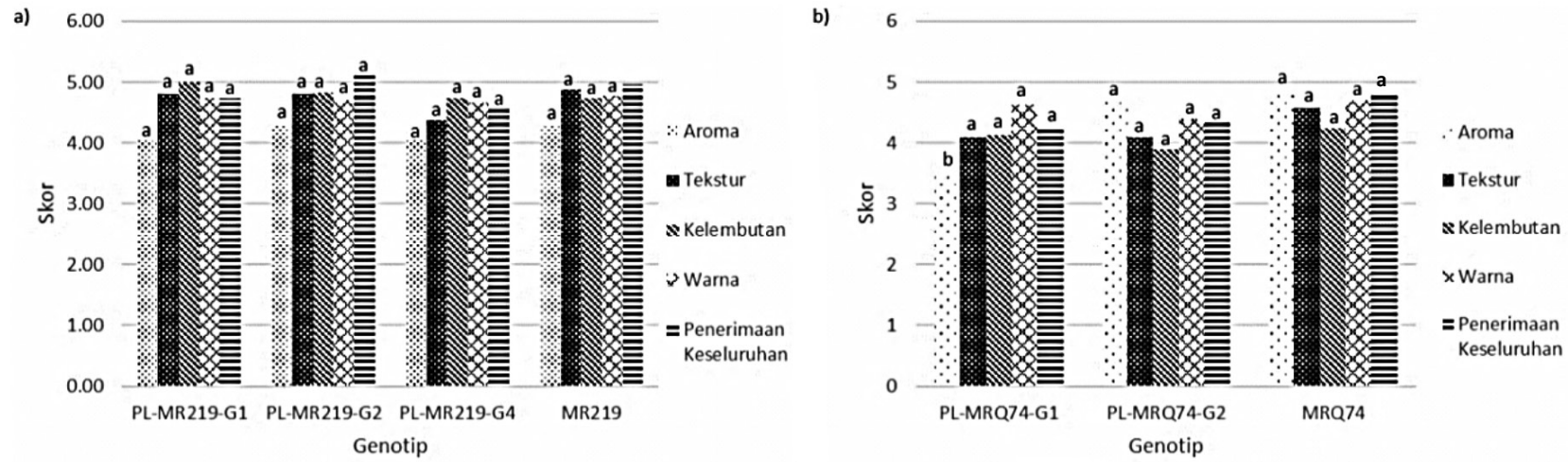

*Abjad pada setiap bar ditanda dengan huruf yang sama tidak menunjukkan perbezaan yang signifikan $(p>0.05)$

RAJAH 1. Purata $(n=30)$ skor penilaian sensori terhadap atribut aroma, tesktur, kelembutan, warna dan penerimaan keseluruhan bagi a) MR219 serta PLnya dan b) MRQ74 dan PLnya 
Menurut Aminah (2004), warna berperanan dalam memenuhi selera manusia dan dikatakan menjadi salah satu ciri deria utama dalam makanan termasuklah aroma, kelikatan, kemasaman dan rasa asing (Birch et al. 1977). Keputusan kajian bagi atribut warna menunjukkan tiada perbezaan yang signifikan antara ketiga-tiga PL MR219 yang diuji berbanding MR219 (Rajah 1(a)). Julat min skor atribut warna adalah daripada 4.67 sehingga 4.77 dan yang tertinggi adalah sampel nasi MR219. Menurut kajian yang dijalankan oleh Suwansri et al. (2002), pengguna memilih beras Jasmine berdasarkan warnanya, berbanding ciri sensori yang lain seperti rasa, aroma, kelikatan serta kekerasan. Tambahan lagi, di Amerika Syarikat hanya kurang daripada $1 \%$ sahaja beras beraroma domestik yang terjual. Hal ini disebabkan oleh beras tersebut berwarna putih pucat serta tidak beraroma (Goodwin et al. 1992). Keputusan ujian hedonik nasi bagi atribut aroma menunjukkan julat min skor bagi atribut warna untuk populasi MQ74 adalah 4.40 sehingga 4.70. Sampel nasi MRQ74 mempunyai skor tertinggi (4.70) manakala PLMRQ74-G1 mempunyai skor terendah iaitu 4.40. Namun, tiada perbezaan yang signifikan untuk attibut warna antara kesemua sampel populasi MRQ74 yang diuji.

Penerimaan keseluruhan bagi penilaian ini adalah bergantung kepada keempat-empat atribut yang diuji iaitu aroma, tekstur, kelembutan serta warna dan pengguna akan memilih sampel nasi yang mereka lebih gemari. Bagi populasi MR219, skor bagi penerimaan keseluruhan menunjukkan sampel nasi PL-MR219-G2 menunjukkan min skor yang tertinggi iaitu 5.10, diikuti induk MR219 (4.97), PL-MR219-G1 (4.73) dan akhir sekali adalah PLMR219-G3 (4.60). Namun, tiada perbezaan yang signifikan antara keempat-empat sampel nasi yang diuji direkodkan (Rajah 1(a)). Hal ini mengesahkan bahawa PL-MR219-G2 telah mengatasi induk MR219 secara keseluruhannya. Oleh itu, beras PL-MR219-G2 dijangka mampu bersaing dan mengatasi beras komersial MR219 yang telah lama berada dalam pasaran Malaysia. Bagi populasi MRQ74 pula, julat min skor bagi penerimaan keseluruhan adalah 4.27 sehingga 4.83. MRQ74 mempunyai min skor yang paling tinggi dengan min skor 4.83 diikuti PL-MRQ74-G2 (4.37) dan PL-MRQ74-G1 (4.27). Namun, tiada perbezaan yang signifikan direkodkan antara kesemua sampel yang diuji. Ini bermakna kedua-dua PL MRQ74 ini juga mempunyai nilai komersial.

\section{UJIAN PENYUSUNAN}

Ujian penyusunan dijalankan bertujuan untuk membandingkan beberapa sampel mengikut kesukaan atribut (Pimentel et al. 2016). Kajian ini dijalankan untuk melihat tahap kesukaan tiga atribut iaitu aroma, rasa dan tekstur terhadap sampel nasi. Bagi ujian penyusunan, panel menilai darjah aroma, rasa dan tekstur berdasarkan skor mengikut kategori iaitu skor 1 bagi kategori kurang wangi/kurang manis/sangat mampat, skor 2 bagi kategori sederhana wangi/sederhana manis/mampat, skor 3 bagi kategori wangi/manis/sederhana berderai dan skor 4 bagi kategori sangat wangi/sangat manis/berderai bagi populasi MR219. Bagi populasi MRQ74 pula, skor 1 bagi kategori kurang wangi/kurang manis/mampat, skor 2 bagi kategori wangi/ manis/sederhana berderai dan skor 3 bagi kategori sangat wangi/sangat manis/berderai kerana hanya mempunyai tiga sampel. Dalam ujian penyusunan, tiada perbezaan yang signifikan antara PLs dan induk untuk kesemua atribut ditunjukkan bagi kedua-dua populasi (Rajah 3 dan 4).

Untuk populasi MR219, julat skor ujian penyusunan bagi atribut aroma adalah antara 2.20 hingga 2.63 iaitu dalam kategori sederhana wangi hingga wangi. Tiga sampel dikategorikan sebagai wangi iaitu MR219 dan PLMR219-G2, masing-masing dengan skor tertinggi iaitu 2.63 diikuti PL-MR219-G4 dengan skor 2.53 (Rajah 3a). Bagi tahap kesukaan pula, julatnya adalah antara 2.33 sehingga

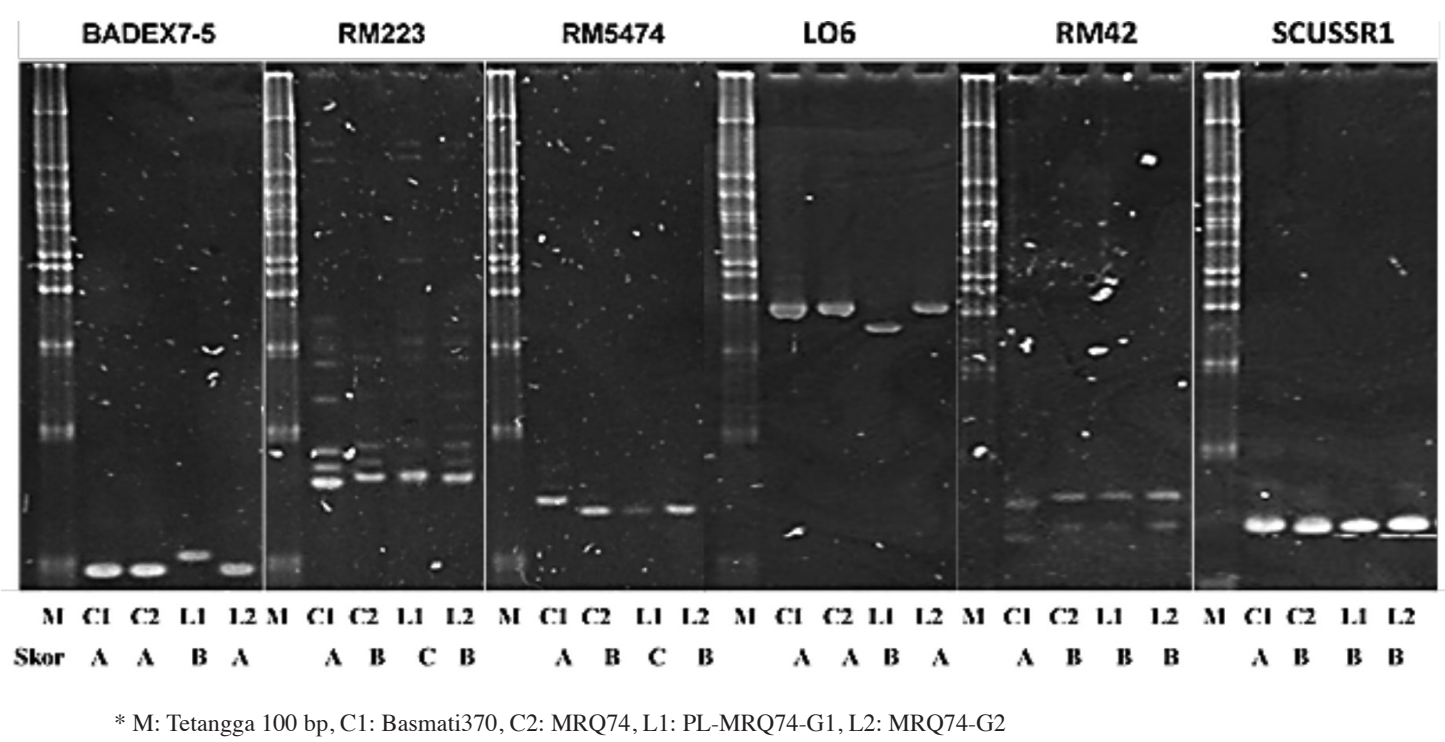

RAJAH 2. Hasil PCR bagi pengesahan kehadiran alel badh2 
2.57. MR219 dan PL-MR219-G4 merupakan genotip paling disukai panel berdasarkan attibut aroma dengan skor yang sama iaitu 2.57 diikuti dan PL-MR219-G2 dengan skor 2.53 (Rajah 4(a)).

Bagi populasi MRQ74 pula, julat skor ujian penyusunan bagi atribut aroma adalah antara 1.77 hingga 2.17 iaitu semua genotip dalam kategori wangi dengan MRQ74 mempunyai skor tertinggi iaitu 2.17 (Rajah 3(b)). Bagi tahap kesukaan pula, julatnya adalah antara 1.87 sehingga 2.10. MRQ74 merupakan genotip paling disukai panel dengan skor atribut aroma adalah 2.10 diikuti PLMRQ74-G2 (Rajah 4(b)). Ini menyokong hasil kajian hedonik yang menunjukkan bahawa MRQ74-G2 turut mempunyai aroma yang wangi seperti MRQ74 berdasarkan pengesahan kehadiran alel badh2. Keputusan daripada ujian penyusunan ini menunjukkan bahawa panel menggemari nasi yang mempunyai aroma yang wangi manakala nasi yang kurang wangi tidak menjadi pilihan.

Rasa adalah faktor yang paling mempengaruhi pemilihan pengguna terhadap makanan dan rasa dibahagikan kepada lima rasa yang utama iaitu manis, masam, masin, pahit dan umami (Barrett et al. 2010). Menurut Yamaguchi dan Ninomiya (2000), umami merupakan rasa yang dikaitkan dengan garam asid amino dan nukleotida dan boleh diertikan sebagai rasa yang enak dan penuh dengan perisa. Untuk ujian penyusunan atribut rasa pula, julat skor bagi populasi MR219 adalah antara 2.27 hingga 2.70 iaitu dalam kategori sederhana manis hingga manis dengan MR219 dan PL-MR219-G1 dikategori sebagai manis dengan skor tertinggi iaitu 2.70 (Rajah 3(a)). Bagi tahap kesukaan untuk atribut rasa pula, julatnya adalah antara 2.27 sehingga 2.73. MR219 merupakan genotip yang mempunyai rasa paling disukai panel dengan skor 2.73 diikuti PL-MR219-G1 dengan skor 2.57 (Rajah 4(a)).

Bagi populasi MRQ74 pula, julat skor ujian penyusunan bagi atribut rasa adalah antara 1.90 hingga 2.07 dengan semua genotip dikategorikan sebagai manis. PL-MRQ74-G2 mempunyai skor ujian penyusunan tertinggi iaitu 2.07 menunjukkan ia mempunyai rasa paling manis antara ketiga-tiga sampel (Rajah 3(b)). Bagi tahap kesukaan pula, julatnya adalah antara 1.97 sehingga 2.80 . MRQ74 merupakan genotip paling disukai panel daripada segi rasa dengan skor 2.80 diikuti PL-MRQ74-G2 dengan skor 2.03 (Rajah 4(b)).

Akhir sekali adalah ujian penyusunan untuk atribut tekstur dengan julat skor bagi populasi MR219 adalah antara 2.37 hingga 2.77 iaitu dalam kategori sederhana mampat hingga sederhana berderai. Nasi PL-MR219-G4 dengan skor tertinggi (2.77) dan PL-MR219-G1 dengan skor kedua tertinggi (2.50) dikategori sebagai sederhana mampat manakala dua lagi sampel dikategorikan sebagai sederhana berderai termasuk induk MR219 (Rajah 3(a)). Bagi tahap kesukaan untuk atribut tekstur pula, julatnya adalah antara 2.47 sehingga 2.53. MR219 merupakan genotip yang mempunyai tekstur paling disukai panel dengan skor 2.53 diikuti PL-MR219-G1 dan PL-MR219-G1 dengan skor yang sama iaitu 2.50 dan akhir sekali adalah PL-MR219-G4 dengan skor 2.47 (Rajah 4(a)).

Bagi populasi MRQ74 pula, julat skor ujian penyusunan bagi atribut tekstur adalah antara 1.73 hingga 2.17 dengan semua genotip dalam kategori sederhana berderai namun induk MRQ74 mempunyai skor tertinggi iaitu 2.17 diikuti PL-MRQ74-G1 dengan skor 2.10 (Rajah 3(b)). Bagi tahap kesukaan pula, julatnya adalah antara 1.87 sehingga 2.07 . PL-MRQ74-G1 dan MRQ74 merupakan genotip paling disukai panel daripada segi tekstur dengan skor yang sama iaitu 2.07 (Rajah 4(b)). Keputusan menunjukkan bahawa panel menyukai nasi yang berderai berbanding mampat kerana nasinya tidak melekat.

Kaedah MAB merupakan kaedah pembiak bakaan yang cepat dan efektif dalam menambah baik sesuatu ciri. Namun, beberapa perkara perlu diambil kira bagi memastikan keberkesanan kaedah MAB iaitu: memastikan gen/QTL yang ingin dipindahkan merupakan gen/QTL major dengan kesan yang konsisten, menggunakan saiz populasi yang besar bergantung kepada bilangan gen/QTL yang dipindahkan (Servin et al. 2004), menggunakan penanda molekul yang rapat dan meliputi keseluruhan saiz gen/QTL yang ingin dipindahkan bagi mengelakkan seretan pindah silang (Neeraja et al. 2007; Servin \& Hospital 2002) dan
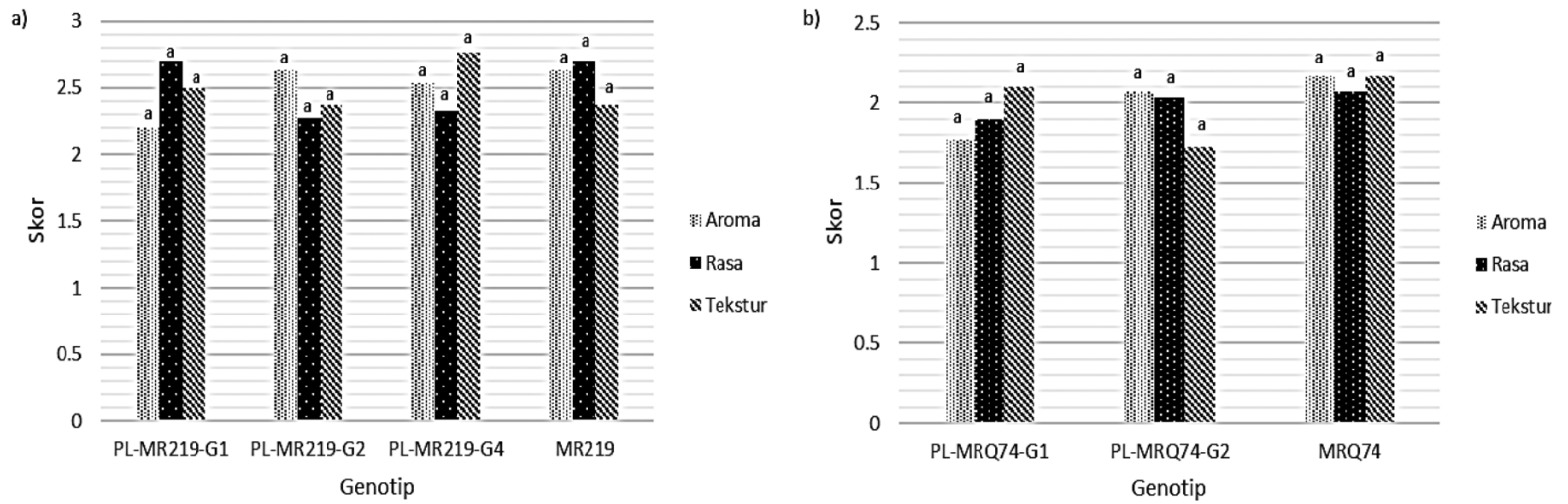

*Abjad pada setiap bar ditanda dengan huruf yang sama tidak menunjukkan perbezaan yang signifikan (LSD, $p>0.05$ )

RAJAH 3. Purata skor ujian penyusunan terhadap atribut aroma, rasa dan tekstur bagi a) MR219 serta plnya dan, b) MRQ74 dan PLnya 

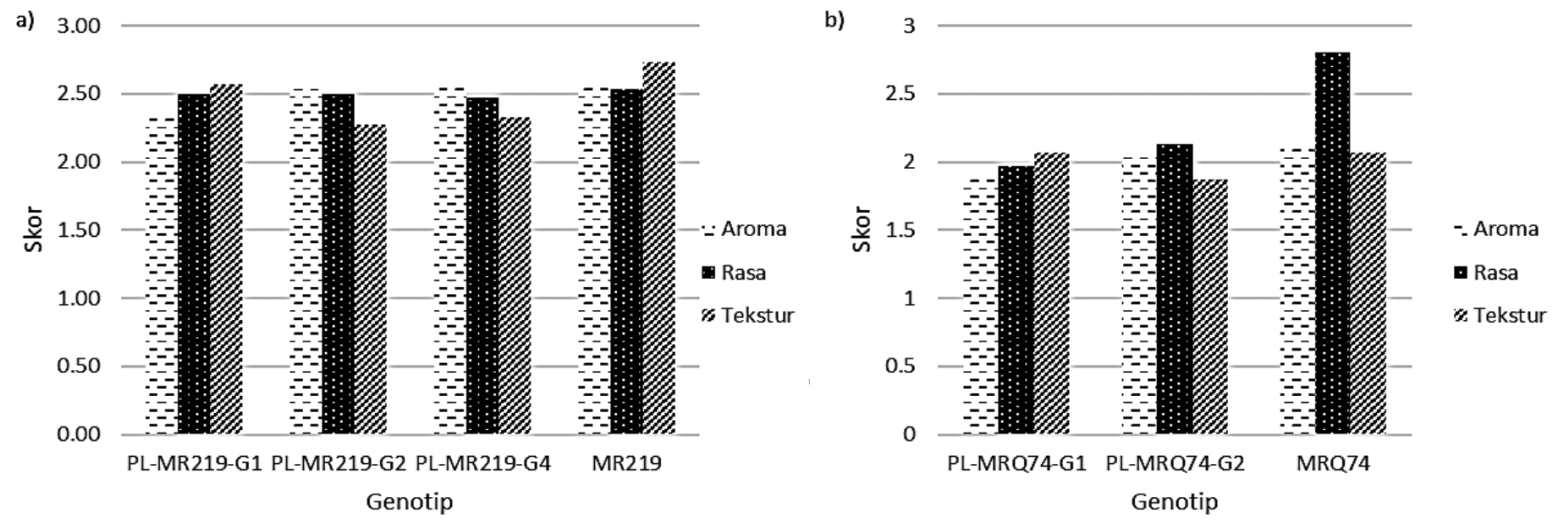

RAJAH 4. Purata skor tahap kesukaan terhadap atribut aroma, rasa dan tekstur bagi a) MR219 serta PLnya dan b) MRQ74 dan PLnya

menjalankan penggenotipan latar belakang menggunakan penanda molekul yang meliputi keseluruhan genom padi bagi memastikan ciri baik induk penerima kekal dalam populasi progeni yang dihasilkan (Shamsudin et al.2016a, 2016b). Pengesahan peratusan kandungan genom induk penerima (kultivar komersial) dalam PLs yang dihasilkan amat penting bagi memastikan ciri-ciri baik seperti ciri kualiti beras dan nasi yang tinggi dibawa oleh PLs terpilih. Ahli biak baka perlu memastikan bahawa pemilihan titisan dilakukan bukan hanya untuk mencapai sesuatu objektif tertentu seperti menghasilkan padi baru yang tahan tekanan abiotik dan biotik dengan potensi hasil yang tinggi sebaliknya ciri kualiti juga perlu diberi perhatian agar titisan padi baru yang dihasilkan dapat diterima oleh pengguna.

\section{KESIMPULAN}

Kesemua PL MR219 dan PL MRQ74 dalam kajian ini kecuali PL-MR216-G1 mempunyai nilai AC kelas sederhana dengan nilai tidak melebihi $25 \%$, GT kelas sederhana $\left(70-74^{\circ} \mathrm{C}\right)$ dan GC kelas lembut (61-100 mm). AC sederhana iaitu antara $20 \%$ hingga $25 \%$ menunjukkan bahawa PLs menghasilkan nasi yang tidak melekit, lembut dan peroi. AC melebihi $25 \%$ pula menandakan sesuatu kultivar tersebut akan menghasilkan tekstur nasi yang kering, peroi dan tidak melekit. GC kelas lembut menandakan bahawa kultivar akan menghasilkan tekstur nasi yang kekal lembut selepas dimasak dan disejukkan. GT sederhana pula menandakan tempoh memasak yang cepat. PLs mempunyai nasi yang tidak melekit dan peroi apabila dimasak, kekal lembut walaupun telah sejuk serta tempoh memasak yang tidak terlalu panjang. PLS MR219 dan PLS MRQ74 juga berbentuk tirus namun beras PL MRQ74 adalah lebih tirus berbanding PL MR219. Selain itu, semua PL dan induk mempunyai nilai ER melebihi 1.25 melainkan PL-MRQ74-G2 menunjukkan bahawa selain PL-MRQ74-G2, PL lain menghasilkan nasi yang panjang setelah masak. Bentuk beras tirus dan nasi yang panjang merupakan pilihan rakyat Malaysia dan dikategorikan sebagai berkualiti tinggi.
Bagi ujian sensori, sampel nasi MR219 dan PLnya menunjukkan tiada perbezaan yang signifikan $(p>0.05)$ terhadap kesemua atribut yang diuji. Walau bagaimanapun, nasi yang paling disukai adalah PL-MR219-G2 dengan nilai min yang paling tinggi iaitu 5.10 berbanding nasi lain. Begitu juga dengan PLS MRQ74 dan MRQ74, tiada perbezaan signifikan $(p<0.05)$ antara kesemua atribut yang diuji kecuali atribut aroma yang menunjukkan MRQ74 berbeza secara signifikan $(p<0.05)$ dengan PL-MRQ74-G1 namun tidak PL-MRQ74-G2. Sampel nasi MRQ74 memiliki skor min yang paling tinggi iaitu 4.83 menunjukkan paling disukai ramai. Namun begitu, pengguna juga menggemari kedua-dua PLs disebabkan oleh tiada perbezaan yang signifikan antara semua sampel nasi. Ujian penyusunan pula menunjukkan bahawa panel menggemari nasi yang manis, beraroma dan berderai dan skor yang tinggi untuk kesemua atribut menjadi pilihan panel. Kesemua atribut tidak menunjukkan perbezaan yang signifikan kecuali atribut aroma bagi populasi MRQ74 dalam ujian sensori menunjukkan bahawa kaedah MAB langkah demi langkah dapat membantu mengekalkan ciri induk penerima yang diingini walaupun QTL bagi ciri lain daripada induk penderma turut dipindahkan.

Secara keseluruhannya, PL MR219 dan PL MRQ74 yang dihasilkan melalui MAB langkah demi langkah ini boleh dikomersialkan kerana mempunyai ciri fisio-kimia dan kualiti beras dan nasi yang memenuhi cita rasa penduduk Malaysia setanding dengan induk MR219 dan MRQ74 serta kultivar mega lain di pasaran tempatan. Kaedah MAB langkah demi langkah merupakan kaedah yang efektif dalam memperkenalkan sesuatu ciri daripada induk penderma ke dalam kultivar mega yang merupakan induk penerima selain dapat mengekalkan ciri yang diingini daripada kultivar mega tersebut.

\section{PENGHARGAAN}

Setinggi-tinggi penghargaan diucapkan kepada Pusat Inovasi Kolaboratif (PIK), UKM atas dana penyelidikan ETP-2015-002 selain menyediakan fasiliti yang lengkap untuk menjalankan kajian ini. Terima kasih juga kepada 
Pusat Pengurusan Penyelidikan dan Instrumentasi (CRIM), UKM atas dana penyelidikan GUP-2017-033.

\section{RUJUKAN}

Adu-Kwarteng, E., Ellis, W.O., Oduro, I. \& Manful, J.T. 2003. Rice grain quality: A comparison of local varieties with new varieties under study in Ghana. Food Control 14(7): 507-514.

Aminah, A. 2004. Prinsip Penilaian Sensori. Bangi: Penerbit Universiti Kebangsaan Malaysia.

Anon. 2007. Albert Agriculture and Food; Using 1,000 kernel weight for calculating seeding rate and harvest losses. http// www1.agric.gov.ad/\$department/deptdocs.nfs/all/agdex 8 . Diakses pada 14 Mac 2017.

Asante, M.D. 2017. Breeding rice for improved grain quality. Dlm. Advances International Rice Research, disunting oleh Li, J. Rijeka: Intech. hlm. 69-89.

Asfaliza, R., Othman, O., Saad, A., Abdul Rahman, B. \& Muhammad, H. 2008. Maswangi- varieti padi wangi baru. Buletin Teknologi Tanaman 5: 15-20.

Asfaliza, R., Syahrin, S., Rashid, R.\& Abu, K.A. 2009. Penilaian ex-ante terhadap kebolehlaksanaan pengkomersialan Maswangi (MRQ74). Economic and Technology Management Review 4: 49-56.

Badi, O. 2013. Rice postharvest technology training program on rice quality. https://www.jica.go.jp/project/english/ sudan/001/materials/c8h0vm00007vrgs5-att/rice_quality_ en.pdf. Diakses pada 20 Disember 2017.

Barrett, D.M., Beaulieu, J.C. \& Shewfelt, R. 2010. Color, flavor, texture, and nutritional quality of fresh-cut fruits and vegetables: Desirable levels, instrumental and sensory measurement, and the effects of processing. Critical Reviews in Food Science and Nutrition 50(5): 369-389.

Birch, G.G., Brennan, J. \& Parker, K.J. 1977. Sensory Properties of Foods. London: Applied Science Publishers Ltd.

Cagampang, G.B., Perez, C.M. \& Juliano, B.O. 1973. A gel consistency test for eating quality of rice. Journal of the Science of Food and Agriculture 24(12): 1589-1594.

Cheng, A., Ismail, I., Osman, M. \& Hashim, H. 2012. Simple and rapid molecular techniques for identification of amylose levels in rice varieties. International Journal of Molecular Sciences 13: 6156-6166.

Choi, W.S. 2016. Correlation between instrumental parameter and sensory parameter in the texture of cooked rice. The Korean Journal of Food and Nutrition 29: 605-609.

Dela-Cruz, N.M. \& Khush, G.S. 2000. Rice grain quality evaluation procedures. Aromatic Rices 3: 15-28.

Fitzgerald, M.A., McCouch, S.R. \& Hall, R.D. 2009. Not just a grain of rice: The quest for quality. Trends in Plant Science 14: 133-139.

Fasahat, P., Muhammad, K., Abdullah, A. \& Ratnam, W. 2012. Amylose content and grain length of new rice transgressive variants derived from a cross between $O$. rufipogon and Malaysian rice cultivar MR219. International Journal on Advanced Science, Engineering Information Technology 2(4): 291-294.

Golam, F., NorZulaani, K., Jennifer, A.H., Subha, B., Zulqarnain, M., Osman, M., Nazia, A.M.,Zulqarnian, M. \& Mohammad, O. 2010. Evaluation of kernel elongation ratio and aroma association in global popular aromatic rice cultivars in tropical environment. African Journal of Agricultural Research 5(12): 1515-1522.
Gengler, I. 2009. When people are the instrument: Sensory evaluation methods. ASQ Statistics Division Newsletter 27(4): 8-12.

Goodwin, H.L., Rister, M.E., Branson, R.E., Stansel, J.W., Webb, B.D., Ward, J.B. \& Kunz, K. 1992. Market Potential for Domestic Rice Varieties among Asian Americans. TAMRC report.

IRRI. 2013. Standard Evaluation System for Rice. Los Banos: International Rice Research Institute.

Jabatan Pertanian Malaysia. 2015. Statistik Tanaman Makanan 2015. Putrajaya: Jabatan Pertanian Malaysia.

Juliano, B.O. 1971. A simplified assay for milled-rice amylose. Cereal Science Today 16(11): 334-340.

Juliano, B.O., Blakeney, A.B., Butta, I., Castilli, D., Choundhury, N.H., Iwasaki, T., Shibuya, N., Kongseree, N., Lagos, E.T., Murty, V.S., Paule, C.M., Perez, C.M. \& Webb, B.D. 1982. International cooperative testing on alkaline digestibility values for milled rice. Starke 34: 21-26.

Juliano, B.O., Onate, L.U. \& del Mundo, A.M. 1965. Relation of starch composition, protein content, and gelatinization temperature to cooking and eating qualities of milled rice. Food Technology 19(6): 116-121.

Juliano, B.O. \& Duff, B. 1991. Rice grain quality as an emerging priority in national rice breeding programs. Dlm. Rice Grain Marketing and Quality Issues. Los Banos: International Rice Research Institute. hlm. 55-64.

Juliano, B.O. \& Perez, C.M. 1983. Major factors affecting cooked milled rice hardness and cooking time. Journal of Texture Studies 14: 235-243.

Lyon, B.G., Champagne, E.T., Vinyard, B.T., Windham, W.R., Barton, F.E. \& Webb, B.D. 1999. Effects of degree of milling, drying condition and moisture content on sensory texture of cooked rice. Cereal Chemistry 76(1): 56-62.

Melissa, A.F., McCouch, S.R. \& Hall, R.D. 2008. Not just a grain of rice: The quest for quality. Trends in Plant Science 14(3): 133-139.

Moskowitz, H.R. \& Drake, B. 1972. Psychophysical measures of texture. Journal Texture Studies 3: 135-145.

Murray, M.G. \& Thompson, W.F. 1980. Rapid isolation of high molecular weight plant DNA. Nucleic Acids Research 8: 4321-4326.

Mutters, R.G. 1998. Concepts of rice quality. http//www. plantsciences.ucdavis.edu/uccerice/quality/concepts.htm. Diakses pada 12 Mac 2017.

Neeraja, C.N., Maghirang-Rodriguez, R., Pamplona, A., Heuer, S., Collard, B.C.Y., Septiningsih, E.M., Vergara, G., Sanchez, D., Xu, K. \& Ismail, A.M. 2007. A marker-assisted backcross approach for developing submergence-tolerant rice cultivars. Theoretical and Applied Genetics 115: 767-776.

Shamsudin, N.A.A., Swamy, B.M., Ratnam, W., Cruz, M.T.S., Raman,A.\& Kumar, A., 2016a. Marker assisted pyramiding of drought yield qtls into a popular Malaysian rice cultivar, MR219. BMC Genetics 17(1): 30.

Shamsudin, N.A.A., Swamy, B.M., Ratnam, W., Cruz, M.T.S., Sandhu, N., Raman, A.K. \& Kumar, A. 2016b. Pyramiding of drought yield qtls into a high quality Malaysian rice cultivar MRQ74 improves yield under reproductive stage drought. Rice 9(1): 21.

Panaud, O., Chen, X. \& McCouch, S. 1996. Development of microsatellite markers and characterization of simple sequence length polymorphism (SSLP) in rice (Oryza sativa L.). Molecular and General Genetics 252: 597-607. 
Pang, Y., Ali, J., Wang, X., Franje, N.J., Revilleza, J.E., Xu, J. \& $\mathrm{Li}, \mathrm{Z} .2016$. Relationship of rice grain amylose, gelatinization temperature and pasting properties for breeding better eating and cooking quality of rice varieties. PLOS One 11(12): 1-14.

Pimentel, T.C., Gomes da Cruz, A. \& Deliza, R. 2016. Sensory evaluation: Sensory rating and scoring methods. Encyclopedia of Food and Health, New York: Elsevier. pp. 744-749.

Rousset, S., Pons, B.\& Pilandon, C. 1995. Sensory texture profile, grain physico-chemical characteristics and instrumental measurements of cooked rice. Journal of Texture Studies 26: $119-135$

Setyaningsih, D., Apriyantono, A. \& Sari, M.P. 2010. Analisis Sensori untuk Industri Pangan dan Agro. Jakarta: Bharata Karya Aksara.

Servin, B. \& Hospital, F. 2002 . Optimal positioning of markers to control genetic background in marker-assisted backcrossing. Journal of Heredity 93: 214-217.

Servin, B., Martin, O.C., Mezard, M. \& Hospital, F. 2004. Toward a theory of marker-assisted gene pyramiding. Genetics 168 : 513-523.

Shamim, F., Raza, M.A. \& Akhtar, M. 2017. Grain quality attributes of new rice basmati lines of Pakistan. Journal of Agricultural Research and Development 7(1): 75-84.

Slaton, N., Moldenhauer, K., Gibbons, J., Blocker, M., Wilson, C., Dilday, R., Robinson, J. \& Koen, B., 2000. Grain characteristics of rice varieties. University of Arkansas, Cooperative Extension Service, Rice Information Bulletin. p. 146.

Sood, B.C. \& Sadiq, E.A. 1979. Geographical distribution of kernel elongation gene(s) in rice. Indian Journal of Genetics and Plant Breeding 40: 439-342.

Stone, H. \& Sidel, J.L. 1992. Sensory Evaluation Practices. San Diego: Elsevier Academic Press.

Suismono. 2012. Technical guide. Analysis of Paddy Grain and Rice Quality in Madagascar. Centre De Formation Et D'application Du Machinisme Agricole (Cfama), Antsirabe.

Suwansri, S., Meullenet, J.F., Hankins, J.A. \& Griffin, K. 2002. Preference mapping of domestic/imported jasmine rice for US-Asian consumers. Journal of Food Science 67(6): 2420-2431.
Tokpah, E.S. 2010. Seed and grain quality characteristics of some rice varieties in Ghana. Thesis. The Kwame Nkrumah University of Science and Technology (Tidak diterbitkan).

Thomas, R., Nadiah, W.W.A. \& Bhat, R. 2013. Physiochemical properties, proximate composition, and cooking qualities of locally grown and imported rice varieties marketed in Penang, Malaysia. International Food Research Journal 20(3): 1345-1351.

Verma, D.K., Mohan, M., Prabhakar, P.K. \& Srivastav, P.P. 2015. Physico-chemical and cooking characteristics of azad basmati. International Food Research Journal 22(4): 1380-1389.

Yamaguchi, S. \& Ninomiya, K. 2000. Umami and food palatability. Journal of Nutrition 130: 921-926.

Yu, S., Ma, Y. \& Sun, D.W. 2009. Impact of amylose content on starch retrogradation and texture of cooked milled rice during storage. Jurnal of Cereal Science 50: 139-144.

Zainudin, H., Amirrudin, M., Badrulhadza, A., Marzukhi, H. \& Bahagia,A.G.M. 2012. Enam kultivar padi popular MARDI Buletin Teknologi MARDI 1: 01-10.

School of Environmental and Natural Resource Sciences

Faculty of Science and Technology

Universiti Kebangsaan Malaysia

43600 UKM Bangi, Selangor Darul Ehsan

Malaysia

*Pengarang untuk surat-menyurat; email: nora_aziz@ukm.edu. my

Diserahkan: 17 Januari 2018

Diterima: 26 Mac 2018 
LAMPIRAN A

Mastersheet bagi MR219 dan PLs

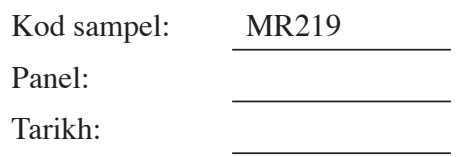

\begin{tabular}{|c|c|c|c|c|c|}
\hline \multirow{2}{*}{ Panel } & \multirow{2}{*}{ Permutasi } & \multicolumn{4}{|c|}{ Kod dan urutan sampel } \\
\hline & & SAMPEL A & SAMPEL B & SAMPEL C & SAMPEL D \\
\hline 1 & $1,2,3,4$ & 269 & 096 & 050 & 001 \\
\hline 2 & $2,1,3,4$ & 940 & 281 & 652 & 225 \\
\hline 3 & $3,1,2,4$ & 752 & 634 & 310 & 900 \\
\hline 4 & $1,3,2,4$ & 045 & 038 & 821 & 138 \\
\hline 5 & $2,3,1,4$ & 306 & 517 & 389 & 229 \\
\hline 6 & $2,4,3,1$ & 080 & 343 & 804 & 569 \\
\hline 7 & $3,2,4,1$ & 674 & 960 & 320 & 239 \\
\hline 8 & $2,3,4,1$ & 757 & 254 & 065 & 857 \\
\hline 9 & $4,3,2,1$ & 202 & 088 & 597 & 332 \\
\hline 10 & $3,4,2,1$ & 449 & 245 & 965 & 737 \\
\hline 11 & $2,4,3,1$ & 173 & 594 & 346 & 375 \\
\hline 12 & $4,2,3,1$ & 103 & 590 & 818 & 460 \\
\hline 13 & $4,1,3,2$ & 467 & 687 & 733 & 105 \\
\hline 14 & $1,4,3,2$ & 711 & 798 & 988 & 608 \\
\hline 15 & $3,4,1,2$ & 218 & 363 & 293 & 304 \\
\hline 16 & $4,3,1,2$ & 127 & 264 & 207 & 677 \\
\hline 17 & $1,3,4,2$ & 153 & 075 & 556 & 402 \\
\hline 18 & $3,1,4,2$ & 347 & 273 & 669 & 849 \\
\hline 19 & $2,1,4,3$ & 360 & 670 & 151 & 650 \\
\hline 20 & $1,2,4,3$ & 685 & 309 & 964 & 143 \\
\hline 21 & $4,2,1,3$ & 349 & 167 & 370 & 770 \\
\hline 22 & $2,4,1,3$ & 746 & 087 & 526 & 874 \\
\hline 23 & $1,4,2,3$ & 036 & 800 & 181 & 646 \\
\hline 24 & $4,1,2,3$ & 197 & 586 & 462 & 169 \\
\hline 25 & $1,2,3,4$ & 721 & 997 & 930 & 261 \\
\hline 26 & $2,1,3,4$ & 161 & 366 & 247 & 906 \\
\hline 27 & $3,1,2,4$ & 098 & 054 & 540 & 142 \\
\hline 28 & $1,3,2,4$ & 321 & 511 & 471 & 947 \\
\hline 29 & $4,3,2,1$ & 191 & 744 & 750 & 213 \\
\hline 30 & $3,4,2,1$ & 553 & 044 & 272 & 595 \\
\hline
\end{tabular}


LAMPIRAN B

Mastersheet bagi MRQ74 dan PLs

Kod sampel:

MRQ74

Panel:

Tarikh:

\begin{tabular}{|c|c|c|c|c|}
\hline \multirow{2}{*}{ Panel } & \multirow{2}{*}{ Permutasi } & \multicolumn{3}{|c|}{ Kod dan urutan sampel } \\
\hline & & SAMPEL A & SAMPEL B & SAMPEL C \\
\hline 1 & $1,2,3$ & 789 & 450 & 557 \\
\hline 2 & $2,1,3$ & 498 & 716 & 185 \\
\hline 3 & $3,1,2$ & 937 & 623 & 816 \\
\hline 4 & $1,3,2$ & 980 & 762 & 881 \\
\hline 5 & $2,3,1$ & 455 & 778 & 145 \\
\hline 6 & $3,2,1$ & 335 & 476 & 797 \\
\hline 7 & $1,2,3$ & 555 & 668 & 164 \\
\hline 8 & $2,1,3$ & 010 & 104 & 532 \\
\hline 9 & $3,1,2$ & 515 & 743 & 186 \\
\hline 10 & $1,3,2$ & 701 & 035 & 892 \\
\hline 11 & $2,3,1$ & 198 & 639 & 880 \\
\hline 12 & $3,2,1$ & 522 & 642 & 084 \\
\hline 13 & $1,2,3$ & 288 & 071 & 710 \\
\hline 14 & $2,1,3$ & 850 & 647 & 599 \\
\hline 15 & $3,1,2$ & 527 & 222 & 214 \\
\hline 16 & $1,3,2$ & 963 & 742 & 282 \\
\hline 17 & $2,3,1$ & 948 & 998 & 378 \\
\hline 18 & $3,2,1$ & 753 & 277 & 265 \\
\hline 19 & $1,2,3$ & 543 & 563 & 738 \\
\hline 20 & $2,1,3$ & 910 & 528 & 051 \\
\hline 21 & $3,1,2$ & 560 & 899 & 709 \\
\hline 22 & $1,3,2$ & 943 & 681 & 979 \\
\hline 23 & $2,3,1$ & 391 & 508 & 808 \\
\hline 24 & $3,2,1$ & 635 & 463 & 727 \\
\hline 25 & $1,2,3$ & 033 & 404 & 322 \\
\hline 26 & $2,1,3$ & 505 & 843 & 786 \\
\hline 27 & $3,1,2$ & 446 & 653 & 294 \\
\hline 28 & $1,3,2$ & 022 & 397 & 443 \\
\hline 29 & $2,3,1$ & 839 & 630 & 210 \\
\hline 30 & $3,2,1$ & 311 & 658 & 502 \\
\hline
\end{tabular}


Borang Penilaian Sensori Ujian Hedonik bagi MR219 dan PLs

NOMBOR PANEL:

JANTINA: LELAKI/PEREMPUAN

KAUM:

Arahan: Anda diberi 5 sampel nasi untuk dirasa. Sila berkumur dengan air sebelum menguji setiap sampel. Bulatkan penilaian anda pada skala yang diberi.

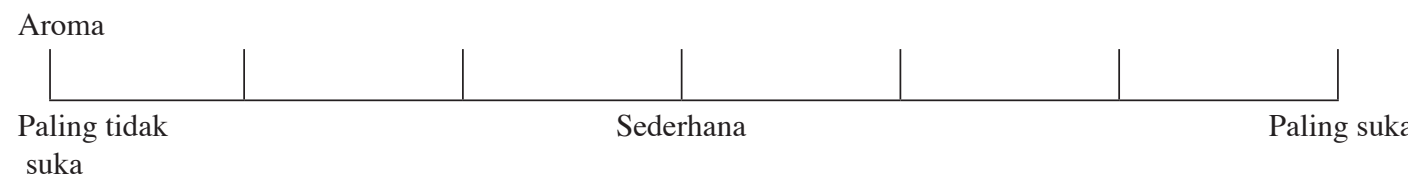

Kelembutan

\begin{tabular}{|l|l|l|l|} 
& & & \\
Paling tidak Paling suka
\end{tabular}
suka

Tekstur

\begin{tabular}{|l|l|l|l|} 
& & & \\
Paling tidak & Sederhana & Paling suka
\end{tabular}

Warna

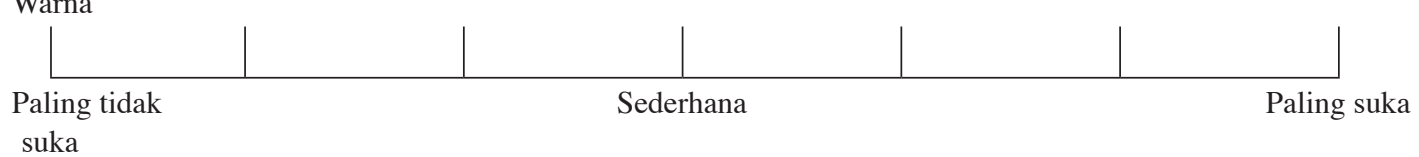

Penerimaan keseluruhan

\begin{tabular}{l|l|l|l|} 
& & & \\
\hline $\begin{array}{l}\text { Paling tidak } \\
\text { suka }\end{array}$
\end{tabular}


LAMPIRAN D

Borang Penilaian Sensori Ujian Hedonik bagi MRQ74 dan PLs

NOMBOR PANEL:

UMUR:

JANTINA: LELAKI/PEREMPUAN

SAMPEL: NASI

KAUM:

Arahan: Anda diberi 3 sampel nasi untuk dirasa. Sila berkumur dengan air sebelum menguji setiap sampel. Bulatkan penilaian anda pada skala yang diberi.

\begin{tabular}{l|c|c|c|} 
Aroma & & & \\
\hline \\
Paling tidak
\end{tabular}

Kelembutan

\begin{tabular}{|l|l|l|l|} 
& & & \\
Paling tidak & Sederhana & Paling suka
\end{tabular}

suka

Tekstur

\begin{tabular}{|l|l|l|l|} 
& & & \\
Paling tidak & Sederhana & Paling suka
\end{tabular}

suka

Warna

\begin{tabular}{l|l|l|l|} 
& $\mid$ & & \\
\hline $\begin{array}{c}\text { Paling tidak } \\
\text { suka }\end{array}$ & Sederhana & Paling suka
\end{tabular}

Penerimaan keseluruhan

\begin{tabular}{|l|c|c|c|} 
& & & \\
\hline Paling tidak & Sederhana & Paling suka
\end{tabular}

suka 


\section{LAMPIRAN E}

Borang Ujian Penyusunan (Ranking) bagi MR219 dan PLs

Panel:

Produk:

Tarikh:

Arahan :

Bilaskan mulut anda sebelum menguji setiap sampel. Susunkan sampel-sampel mengikut darjah aroma (1=kurang wangi, 4=paling wangi) dan darjah kesukaan (1=paling tidak disukai, 4=paling disukai). Mulakan dengan sampel sebelah kiri anda.

Sampel

Aroma

Kesukaan

Panel:

Produk:

Tarikh:

Arahan :

Bilaskan mulut anda sebelum menguji setiap sampel. Susunkan sampel-sampel mengikut darjah rasa (1=kurang manis, 4=sangat manis) dan darjah kesukaan (1=paling tidak disukai, 4=paling disukai). Mulakan dengan sampel sebelah kiri anda.

Sampel

Rasa

Kesukaan

Panel:

Produk:

Tarikh:

Arahan:

Bilaskan mulut anda sebelum menguji setiap sampel. Susunkan sampel-sampel mengikut darjah tekstur (1=mampat, 4=berderai) dan darjah kesukaan (1=paling tidak disukai, 4= paling disukai). Mulakan dengan sampel sebelah kiri anda.

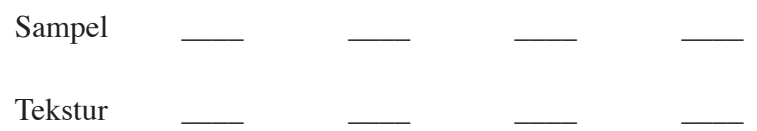

Kesukaan 


\section{LAMPIRAN F}

Borang Ujian Penyusunan (Ranking) bagi MRQ74 dan PLs

Panel:

Produk:

Tarikh:

\section{Arahan:}

Bilaskan mulut anda sebelum menguji setiap sampel. Susunkan sampel-sampel mengikut darjah aroma (1=kurang wangi, $3=$ paling wangi) dan darjah kesukaan (1=paling tidak disukai, 3=paling disukai). Mulakan dengan sampel sebelah kiri anda.

Sampel

Aroma

Kesukaan

Panel:

Produk:

Tarikh:

Arahan:

Bilaskan mulut anda sebelum menguji setiap sampel. Susunkan sampel-sampel mengikut darjah rasa ( $1=$ kurang manis, $3=$ sangat manis) dan darjah kesukaan (1=paling tidak disukai, 3=paling disukai). Mulakan dengan sampel sebelah kiri anda.

Sampel

Rasa

Kesukaan

Panel:

Produk:

Tarikh:

Arahan:

Bilaskan mulut anda sebelum menguji setiap sampel. Susunkan sampel-sampel mengikut darjah tekstur ( $1=$ mampat, $3=$ berderai $)$ dan darjah kesukaan (1=paling tidak disukai, 3= paling disukai). Mulakan dengan sampel sebelah kiri anda.

Sampel

Tekstur

Kesukaan 